\title{
VIRULENCE FACTORS IN VANCOMYCIN-RESISTANT AND VANCOMYCIN- SUSCEPTIBLE ENTEROCOCCUS FAECALIS FROM BRAZIL
}

\author{
I. L. B. C. Camargo ${ }^{1}$; R. C. Zanella ${ }^{2}$; M. S. Gilmore ${ }^{3}$; A. L. C. Darini ${ }^{1 *}$
}

${ }^{1}$ Faculdade de Ciências Farmacêuticas de Ribeirão Preto, Universidade de São Paulo, Ribeirão Preto, SP, Brasil; ${ }^{2}$ Seção de Microbiologia, Instituto Adolfo Lutz, São Paulo, SP, Brasil; ${ }^{3}$ Schepens Eye Research Institute, Harvard Medical School, Boston, MA, USA

Submitted: November 12, 2007; Returned to authors for corrections: December 10, 2007; Approved: February 21, 2008.

\begin{abstract}
Enterococci are members of commensal flora of animals and insects, but are also important opportunistic pathogens. Our objective was to observe if there was any difference of virulence in several groups of $E$. faecalis, mainly between vancomycin-resistant $E$. faecalis (VREFS) of colonization and infection. VREFS and vancomycin-sensitive $E$. faecalis from Brazil were screened for the presence of virulence factor genes. Phenotypic assays were used to assess in vitro expression, to understand the pathogenic potential of these isolates and to determine whether a correlation exists between virulence and antibiotic resistance. Different virulence profiles were found suggesting that the disseminating clone may have generated several variations. However, our study showed that one constellation of traits appeared most commonly: gelatinase, aggregation substance and esp (GEA). These factors are important because they have been implicated in cell aggregation and biofilm formation. Biofilm formation may promote the conjugation of plasmids harboring resistance and virulence genes, enhancing the probability of entry of new resistance genes into species. Curiously, the profile GEA was not exclusive to VREFS, it was the second most observed in VSEFS isolates from colonization and infection in hospitalized patients and also from rectal swabs of healthy volunteers. Such strains appear to represent the entry gateway to new resistance genes into E. faecalis and may contribute to the spreading of $E$. faecalis mainly in hospitals.
\end{abstract}

Key-words: Enterococcus faecalis, VRE, Esp, gelatinase, aggregation substance

\section{INTRODUCTION}

Enterococci are members of the commensal flora of human, animals and insects, but are also important opportunistic pathogens that often posses several vitulence factors and resistance to multiple antibiotics including vancomycin (4). Of the five phenotypes of glycopeptide resistance described $(4,11,26)$ VanA and VanB are the most commom (26).

Cytolysin (Cyl), enterococcal surface protein (Esp), gelatinase (GelE) and aggregation substance (Agg) are among the virulence factors able to influence host/parasite relationships that were described in Enterococcus faecalis $(7,15,21)$. Cytolysin is a hemolytic toxin that also has bacteriocin activity (7). Esp is a surface protein that enhances the biofilm formation by E. faecalis (23). Gelatinase is a metalloprotease that cleaves several substrates including insoluble collagen fragments, as well as the pheromone and inhibitor peptides involved in conjugative plasmid transfer of E. faecalis (25). A role for GelE in biofilm development has also been recently described $(14,15)$. Aggregation substance, encoded by asc 10 , asal and other related genes, is a pheromone-inducible surface protein that promotes aggregation during bacterial conjugation in E. faecalis (5). Some of these factors, including cytolysin, Agg and Esp were found to be encoded on a large, 153-kb pathogenicity island (20). These virulence factors may play a role in promoting persistence of enterococci in the nosocomial

*Corresponding Author. Mailing address: Faculdade de Ciencias Farmaceuticas de Ribeirão Preto - Universidade de São Paulo. Av. do Café s/n - Monte Alegre, Ribeirao Preto, SP, Brasil. CEP: 14040-903. Phone: +55 1636024291 Fax: +55 163602 4725. E-mail: aldarini@fcfrp.usp.br 
environment, and consequently inter and intra-hospitals dissemination.

In Brazil, vancomycin resistant Enterococci (VRE) have been isolated only from hospitalized patients (27) and have not yet been described in animals despite the past use of avoparcin as growth promoter (16). The first VRE strain in Brazil was isolated in 1996 and was E. faecium classified as VanD-4 and ST281 by MLST $(1,10,11)$. However, no other VanD strains have been reported in Brazil. On the other hand, a predominant clone of vancomycin-resistant $E$. faecalis (VREFS) VanA has recently been disseminating throughout hospitals in Sao Paulo and other cities $(8,18,19)$. It was of interest to identify virulence factors and antibiotic resistance profiles among isolates of the disseminating clone and compare them with subsets of vancomycin-sensitive E. faecalis (VSEFS) from several sources in Brazil. In addition, to know the isolate pathogenicities was the base for understanding if a correlation exists between virulence factors and resistance and to determine whether the dissemination of this E. faecalis clone represents an important shift in the spread of vancomycin resistance to more virulent lineages.

\section{MATERIALAND METHODS}

A total of 115 isolates of $E$. faecalis from several regions of Brazil, were divided into two major groups, VREFS (24 isolates) and VSEFS (91 isolates). VREFS isolates were recovered only from hospitalized patients in Brazil, and were subdivided in 2 subsets: 8 VREFS from colonized hospitalized patients (chp) and 16 VREFS from infections in hospitalized patients (ihp). The 91 VSEFS were subdivided into 3 different subsets: 41
VSEFS ihp, 34 VSEFS chp and 16 VSEFS from colonized volunteers within the community (cvc). Species and genotype identification of VRE were performed by PCR as previously described (13). Tests for high-level gentamicin $(500 \mu \mathrm{g} / \mathrm{mL})$ and streptomycin $(2,000 \mathrm{mg} / \mathrm{mL})$ and Minimal Inhibitory Concentrations (MICs) of vancomycin and penicillin were determined by the agar dilution method as recommended by CLSI (6).

Total DNA was prepared as described (21), and $200 \mathrm{ng}$ of each DNA sample was bound to a zeta-probe nylon membrane (Bio Rad, Hercules, California) using a 96 wells microfiltration apparatus (Bio Rad, Bio-Dot ${ }^{\circledR}$ ). The DNA was crosslinked to the membrane using an ultraviolet multilinker (UVC 515, UltraLum, Carson, California, USA), and hybridized to radioactive probes. Genes of interest were amplified by PCR using the primers described in Table 1. The probes were labeled using the RadPrime DNA Labeling System (Invitrogen, California, USA).

Gelatinase production was determined on Todd-Hewitt agar supplemented with $3 \%$ gelatin (22). Cytolysin production was determined by observing $\beta$-hemolysis on BHI agar supplemented with $5 \%(\mathrm{v} / \mathrm{v})$ human erythrocytes. Control strains included: $E$. faecalis JH2SS (pAD1) for the asa1 gene; E. faecalis MMH594 for the genes $a s c 10, c y l L_{L}, c y l L_{S}, c y l A$ and esp; E. faecalis OG1RF for the gelE gene.

Agg expression was detected by the clumping assay (12) with pheromones obtained from $E$. faecalis $\mathrm{FA2}-2$. To precipitate pheromones, an overnight 1:10 culture of plasmid-free $E$. faecalis FA2-2 was subcultured into $200 \mathrm{~mL}$ of THB for $6 \mathrm{~h}$ at $37^{\circ} \mathrm{C}$. The cells were removed by centrifugation, and the supernatant was filtered through a $0.2 \mu \mathrm{m}$ filter $\left(\mathrm{Nalgen}^{\circledR}\right.$, Nalge

Table 1. Primers used to make the specific probes for hybridization.

\begin{tabular}{|c|c|c|c|c|}
\hline Gene & Primer name & Sequence 5'-3' & Lenght of the fragment & Reference \\
\hline \multirow[t]{2}{*}{$c y l L_{\mathrm{L}}$} & $c y l L_{\mathrm{L}} \mathrm{F}$ & AAC TAA GTG TTG AGGAAA TG & $159 \mathrm{bp}$ & (2) \\
\hline & $\operatorname{cylL}_{L} R$ & AAA GAC ACA ACT ACA GTT AC & & \\
\hline \multirow[t]{2}{*}{$\operatorname{cyl} L \mathrm{~s}$} & $c y l L \mathrm{~s} F$ & AGAACTTGTTGG TCC TTC & 134 bp & (2) \\
\hline & $c y l L \mathrm{~s} \mathrm{R}$ & GCT GAAAAT AAT GCA CCT AC & & \\
\hline \multirow[t]{2}{*}{$c y l \mathrm{~A}$} & cylA F & ACA GGT TAT GCA TCA GAT CT & $507 \mathrm{bp}$ & (2) \\
\hline & cylA R & AAT TCACTC TTG GAG CAA TC & & \\
\hline \multirow[t]{2}{*}{$e s p^{* *}$} & Esp14F & AGA TTT CAT CTT TGA TTC TTG G & $500 \mathrm{bp}$ & AF034779* \\
\hline & Esp12R & AAT TGA TTC TTT AGC ATC TGG & & \\
\hline \multirow[t]{2}{*}{ gel $\mathrm{E}$} & gelE F & AATTGCTTTACACGGAACGG & $548 \mathrm{bp}$ & (2) \\
\hline & gelE R & GAGCCATGGTTTCTGGTTGT & & \\
\hline \multirow{2}{*}{$\begin{array}{c}\text { Agg } 1^{* * *} \\
(\text { asa } 1 \text { and } \operatorname{asc} 10)\end{array}$} & Agg $1 \mathrm{~F}$ & AGT GAC GAT TGA TTTATC CAAAGT G & 446bp & $\mathrm{X} 17214$ and \\
\hline & Agg $1 \mathrm{R}$ & CGT TCG GAA GAT TTC ACT TCA TAA T & & \\
\hline
\end{tabular}

* The primers were designed based on the sequences registered in the GenBank. ** The sequences of esp primers were provided by Dr. Nathan Shankar, College of Pharmacy, Oklahoma University Health Sciences Center, OK, USA. *** Primers are the same for amplify both genes, but the templates were different. 
Nunc International, Rochester, NY). Pheromones were precipitated from supernatant with trichloroacetic acid at a final concentration of $5 \%$ for $18 \mathrm{~h}$ at $4^{\circ} \mathrm{C}$. Precipitate was collected by centrifugation at $8410 \mathrm{~g}$ for 15 minutes, dried and dissolved in $10 \mathrm{~mL}$ of Todd Hewitt Broth (THB), and again filtered.

All VRE isolates were typed by pulsed-field gel electrophoresis (PFGE) as described (3). Restriction fragments were separated using Gene Navigator apparatus (Amersham Biosciences) at $180 \mathrm{~V}$ for $25 \mathrm{~h}$, at $7^{\circ} \mathrm{C}$, adjusted for pulse times of $20 \mathrm{~s}$ for $10 \mathrm{~h}, 8 \mathrm{~s}$ for $10 \mathrm{~h}$ and $3 \mathrm{~s}$ for $5 \mathrm{~h}$. PFGE clonal groups were assigned according to the criteria of Tenover et al. (24). The project protocol was approved by the Research Ethical Committee of the Faculty of Pharmaceutical Sciences of Ribeirão Preto, under the number 28/CEP/FCFRP.

Statistical analysis was performed by Fisher's exact test using GraphPad Prism software (San Diego, California, USA).

\section{RESULTS AND DISCUSSION}

PFGE typing of all VREFS in this study confirmed the presence of the VREFS type A strain in several hospitals in different cities of Brazil (Table 2 and Fig.1). All but one VREFS were resistant to penicillin and high levels of gentamicin, but susceptible to streptomycin. The remaining PFGE types, resistance and virulence profiles are shown in Table 2.

Virulence factor profiles were established by determining the presence of the gene and confirming its expression in the phenotypic assays, except for esp. This study has shown that PFGE type A strain appears to have undergone small variations with time, since several virulence profiles were found in different isolates of the same strain. Among the varied virulence profiles, one was the most common among isolates of this disseminating clone. Twelve out 16 type A isolates possessed the GelE, Agg and esp profile (Table 2). Our results suggest that loss of some factors resulted in the variations found in the 4 remaining type A isolates.

Among the VREFS, cytolysin was presented in only one isolate that also produced gelatinase. This isolate was a subtype A1 strain, closely related to the disseminating clone in Brazil. However, another VREFS subtype A1, isolated 2 years later, possessed the GelE, Agg and esp profile. The data suggests that either the first isolate acquired the cytolysin operon,

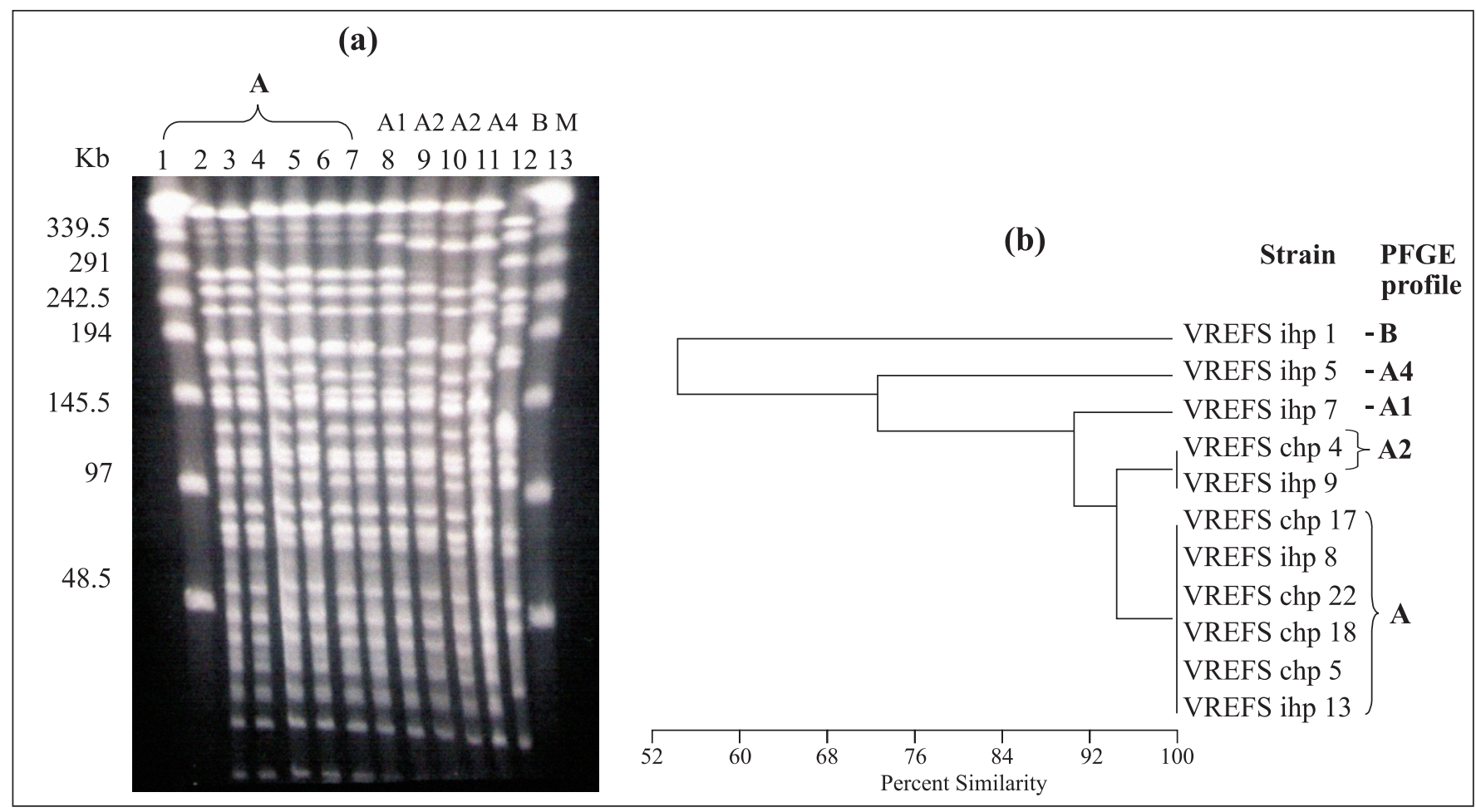

Figure 1. Agarose gel electrophoresis of genomic DNA. a) Results of pulsed-field Gel electrophoresis analysis of VREFS isolated in Brazil. 1- M, Lambda PFMarker (New England BioLabs), 2- VREFS ihp 13, 3- VREFS chp 5, 4- VREFS chp 18, 5- VREFS chp 22, 6 VREFS ihp 8, 7- VREFS chp 17, 8- VREFS ihp 7, 9- VREFS ihp 9, 10- VREFS chp 4, 11- VREFS ihp 25, 12- VREFS ihp 1, 13- M Lambda PFMarker (New England BioLabs); b) Dendrogram of PFGE of the strains calculated with percent similarity performed by MVSP 3.0 software. chp, isolates of hospitalized and colonized patients; ihp, isolates from infection in hospitalized patients. 
Table 2. Date, susceptibility profile, virulence factors and PFGE profile present in vancomycin-resistant $E$. faecalis isolates from Brazil.

\begin{tabular}{|c|c|c|c|c|c|}
\hline \multirow{2}{*}{ Samples } & \multicolumn{2}{|c|}{ Isolation } & \multirow{2}{*}{$\begin{array}{c}\text { Virulence factors } \\
\text { Genes }^{\mathrm{b}} / \text { Expression profile }^{\mathfrak{c}}\end{array}$} & \multirow{2}{*}{$\begin{array}{l}\text { Susceptibility profile } \\
\text { P/HLAR G/HLAR S }{ }^{d}\end{array}$} & \multirow[t]{2}{*}{ PFGE profile } \\
\hline & Date & Source $^{a}$ & & & \\
\hline \multicolumn{6}{|l|}{ VREFS chp ${ }^{\mathrm{e}}$} \\
\hline 4 & 1998 & CSSM-SP & gelE, asal, asc10 esp / GAE & $\mathrm{R} / \mathrm{R} / \mathrm{S}$ & A2 \\
\hline 5 & 1998 & CSSM-SP & gelE, asal, asc10 esp / GAE & $\mathrm{R} / \mathrm{R} / \mathrm{S}$ & A \\
\hline 6 & 1998 & CSSM-SP & asal, asc10 esp / $\mathrm{AE}$ & $\mathrm{R} / \mathrm{R} / \mathrm{S}$ & A \\
\hline 18 & 1999 & HCSP-SP & gelE, asal, asc10 esp / GAE & $\mathrm{R} / \mathrm{R} / \mathrm{S}$ & A \\
\hline 22 & 2000 & HCASP-SP & gelE, asal, asc10 esp / GAE & $\mathrm{R} / \mathrm{R} / \mathrm{S}$ & A \\
\hline 24 & 1998 & CSSM-SP & gelE, asa1, asc10 esp / AE & $\mathrm{R} / \mathrm{R} / \mathrm{S}$ & $\mathrm{C}$ \\
\hline 17 & 1999 & CSSM-SP & gele, asa1, asc10 esp / GAE & $\mathrm{R} / \mathrm{R} / \mathrm{S}$ & $\mathrm{A}$ \\
\hline 23 & 1999 & HSPSP-SP & gelE, asal, asc10 esp / GAE & $\mathrm{R} / \mathrm{S} / \mathrm{S}$ & A \\
\hline \multicolumn{6}{|l|}{ VREFS ihp ${ }^{\mathrm{f}}$} \\
\hline 1 & 1998 & CSSM-SP & gelE, asa1, asc10/ $\mathrm{N}$ & $\mathrm{R} / \mathrm{R} / \mathrm{S}$ & B \\
\hline 2 & 1998 & CSSM-SP & gelE, asal, asc10 esp / GAE & $\mathrm{R} / \mathrm{R} / \mathrm{S}$ & $\mathrm{A}$ \\
\hline 3 & 1998 & CSSM-SP & gelE,cylL $L_{L} L_{S} A$, asal, asc $10 / \mathrm{GC}$ & $\mathrm{R} / \mathrm{R} / \mathrm{S}$ & A1 \\
\hline 7 & 2000 & HEDPA-RS & gelE, asal, asc10 esp / GAE & $\mathrm{R} / \mathrm{R} / \mathrm{S}$ & A1 \\
\hline 8 & 2000 & HPUCP-RS & gelE, asal, asc10 esp / GAE & $\mathrm{R} / \mathrm{R} / \mathrm{S}$ & A \\
\hline 9 & 2000 & HCC-PR & gelE, asal, asc10 esp / GAE & $\mathrm{R} / \mathrm{R} / \mathrm{S}$ & A2 \\
\hline 10 & 2000 & HCC-PR & gelE, asal, asc10 esp / GAE & $\mathrm{R} / \mathrm{R} / \mathrm{S}$ & $\mathrm{A} 3$ \\
\hline 11 & 1999 & CSSM-SP & gelE, asal, asc10 esp / GAE & $\mathrm{R} / \mathrm{R} / \mathrm{S}$ & A \\
\hline 12 & 1999 & CSSM-SP & gelE, asal, asc10 esp / GAE & $\mathrm{R} / \mathrm{R} / \mathrm{S}$ & $\mathrm{A}$ \\
\hline 13 & 1999 & CSSM-SP & gelE, asal, asc10 esp / GAE & $\mathrm{R} / \mathrm{R} / \mathrm{S}$ & A \\
\hline 14 & 1999 & CSSM-SP & gelE, asa1, asc10/GA & $\mathrm{R} / \mathrm{R} / \mathrm{S}$ & A \\
\hline 15 & 1999 & CSSM-SP & gelE, asal, esp / GAE & $\mathrm{R} / \mathrm{R} / \mathrm{S}$ & A \\
\hline 16 & 1999 & CSSM-SP & gelE, asa 1, asc10 esp / GAE & $\mathrm{R} / \mathrm{R} / \mathrm{S}$ & A \\
\hline 20 & 2000 & CSSM-SP & gele, asal, asc10 esp / GE & $\mathrm{R} / \mathrm{R} / \mathrm{S}$ & A \\
\hline 21 & 1999 & HSPSP-SP & gelE, asa1, asc10 esp / G & $\mathrm{R} / \mathrm{R} / \mathrm{S}$ & A \\
\hline 25 & 2003 & UFU - MG & gelE, asal, asc10 esp / GAE & $\mathrm{R} / \mathrm{R} / \mathrm{S}$ & A4 \\
\hline
\end{tabular}

${ }^{a}$ CSSM-SP - Casa de Saúde Santa Marcelina - SP, HCSP-SP- Hospital do Coração de São Paulo, HSPSP-SP - Hospital do Servidor Público de São Paulo, HED PA - RS- Hospital Ernesto Dornelles - Porto Alegre - RS, HPUCPA - RS- Hospital da Pontifícia Universidade Católica de Porto Alegre - RS, HCC-PR - Hospital das Clínicas de Curitiba - PR, HCASP-SP - Hospital Cruz Azul - SP, UFU - MG, Universidade Federal de Uberlandia. ${ }^{\mathrm{b}}$ gelE, gelatinase gene; $c y l L_{L} L_{S} A$, cytolysin genes; asal and asc10 are aggregation substance's genes; esp, enterococcal surfae protein gene. ${ }^{\mathrm{c}} \mathrm{G}$, gelatinase, A, aggregation, E, esp presence, C, cytolysin activity, N, none of the virulence factors studied found were expressed. ${ }^{\mathrm{d}} \mathrm{P}$, penicillin, HLAR G, high level aminoglycoside resistance - gentamycin, HLAR S, high level Aminoglycoside resistance - streptomycin, R, resistant and S, susceptible. ${ }^{\mathrm{e}} \mathrm{chp}$, isolates of hospitalized colonization patients. ${ }^{\mathrm{f}}$ ihp, isolates of infection in hospitalized patients.

perhaps on a conjugative plasmid, but lost esp, or had not acquired it yet. In addition, both Agg genes were detected in the strain, but not their expression. In our study, the total incidence of cytolysin among VSEFS isolates was $12 \%$ (11 out of 91), in concordance with reported observations (9).

The presence of the gelatinase gene by itself, for instance, does not ensure its expression. The expression of virulence factor's gene may be controlled by a very complex regulation network and is not the focus of this study. On the other hand, some VSEFS isolates were positive for clumping but lacked the two aggregation substance genes studied, indicating that other
Agg genes may be involved in the aggregation by some VSEFS. This was especially true in the VSEFS cvc group, among which $31.2 \%$ were positive by phenotypic assay, but negative for asc 10 and asal. Strains with asal and asc 10 genes, but negative in phenotypic assays, were also found suggesting that the presence of these genes may not predict their expression. In summary, asal and asc10 are present and expressed in a large number of VREFS isolates, but greater variability exists in VSEFS isolates.

Subtypes A2, A3 and A4 were isolated in different periods of time, but presented the same GelE, Agg and esp virulence profile. The only VREFS type $\mathrm{C}$ strain in this study showed the 
Agg-esp profile and had a non-expressed gelE gene. Finally, there was only one VREFS type B in this study that in spite of having gelE and Agg genes did not express them. Therefore, it did not fit any of the virulence factor profiles. Only one of the VSEFS strains (chp group) did not possess any of the virulence factor genes tested but another VSEFS (ihp group) possessed all. There was no absolute correlation between the presence of particular virulence factors and resistance to the antibiotics in the VSEFS isolates (data not shown). Factors GelE, Agg, Cyl and esp were detected in isolate VSEFS iph JF7 which was sensitive to all antibiotics. Resistance to penicillin was observed in all VREFS, most were also resistant to high level gentamicin but all were sensitive to high level streptomycin (Table 2)

Marques et al. (17) described that there was no significant association between virulence factor markers and clinical sources in a different set of strains isolated in Brazil. The most frequent genotypic profile detected by Marques et al. (17) was efa (adhesin), esp and gelE. We did not search for efa in our work, but in both VREFS and VSEFS groups, most isolates exhibited the following profiles: Agg and esp, or GelE, Agg and $e s p$. All VSEFS subsets showed profiles as, esp only, gelatinase only, and Cyl, Agg and esp. Profiles GelE and Cyl, and GelE and Agg were detected among VSEFS from colonized volunteers of the community, and from infections in hospitalized patient. Agg occurring by itself was found only in VSEFS from colonization subsets.

In conclusion, there was no difference statistically significant in the frequency of the virulence factor's genes found in the type A strains (Table 2) when compared both groups of VREFS (chp and ihp) (Fisher's exact test, $\mathrm{p}=0.59$ ). The virulence factors GelE, Agg and esp occur together in most VREFS type A isolates, the disseminating clone occurring in Brazil. However, this constellation of traits is not exclusive of VREFS but it was also observed in VSEFS isolates of colonization and infection patients as well as of healthy colonization volunteers. These factors have all been shown by other investigators to aggregate cells, to contribute to biofilm formation and to be particularly important in the dissemination or acquisition of resistances by promoting cell-cell contact and the conjugal transfer of plasmids harboring resistance and virulence genes. Such strains appear to represent the entry gateway to new resistance genes into $E$. faecalis and may contribute to the spreading of E. faecalis mainly in the hospitals.

\section{ACKNOWLEDGEMENTS}

We thank H. Sadder, L. Dalla Costa, A. L. Barth, P. Gontijo, N. Shankar for providing the strains for this study; I. C. V. Palazzo, J. Ferreira and A. S. Bagdahyan for technical assistance and C. Pillar for helpful discussions and critical reading of the manuscript. FAPESP(02/11518-6) and CAPES (BEX1684/03) financially supported this work.

\section{RESUMO}

\section{Fatores de virulência em Enterococcus faecalis resistentes e suscetível à vancomicina isolados no Brasil}

Enterococci são membros da microbiota comensal de animais e insetos, mas também são importantes patógenos oportunistas. Nosso objetivo foi observar se há qualquer diferença na virulência nos diversos grupos de Enterococcus faecalis, principalmente nos E. faecalis resistente à vancomicina (VREFS) isolados de colonização e infecção. VREFS e E. faecalis sensíveis à vancomicina (VSEFS) do Brasil foram pesquisadas quanto a presença de fatores de virulência. Ensaios fenotípicos foram usados para obter a expressão in vivo, entender o potencial patogênico destas amostras e determinar se existe correlação entre virulência e resistência a antibióticos. Diferentes perfis de virulência foram encontrados sugerindo que o clone que está se disseminado pode ter gerado diversas variações. No entanto, nosso estudo mostrou que um conjunto de fatores parece ser mais comum entre as amostras: gelatinase, substância de agregação e esp (GEA). Estes fatores tem sido correlacionados com a agregação de células e formação de biofilmes. A formação de biofilme pode promover a conjugação de plasmídeos contendo genes de resistência entre as espécies. Curiosamente, o perfil GAE não foi exclusivo para VREFS, foi o segundo mais observado em amostras VSEFS provenientes de colonização e infecção em pacientes hospitalizados e também de swabs retais de voluntários saudáveis. Tais linhagens pacerem representar a "porta de entrada" para novos genes de resistência em $E$. faecalis e podem contribuir para a disseminação de $E$. faecalis principalmente nos hospitais.

Palavras-chave: Enterococcus faecalis, VRE, Esp, gelatinase, substância de agregação

\section{REFERENCES}

1. Camargo, I.L.B.C.; Dalla Costa, L.M.; Woodford, N.; Gilmore, M.S.; Darini, A.L.C. (2006). Sequence analysis of Enterococcus faecium strain 10/96 A (VanD4), the original vancomycin-resistant E. faecium strain in Brazil. J. Clin. Microbiol., 44, 2635-2637.

2. Camargo, I.L.B.C.; Gilmore, M.S.; Darini, A.L.C. (2006). Multilocus sequence typing and analysis of putative virulence factors in vancomycin-resistant and vancomycin-sensitive Enterococcus faecium strains isolated in Brazil. Clin. Microbiol. Infect., 11, 11231130.

3. Campanile, F.; Bartoloni, A.; Bartalesi, F. et al. (2003). Molecular alterations of VanA element in vancomycin-resistant enterococci isolated during a survey of colonized patients in an Italian intensive care unit. Microb. Drug Resist., 9, 191- 199.

4. Cetinkaya, Y.; Falk, P.; Mayhall, C.G. (2000). Vancomycin-resistant enterococci. Clin. Microbiol. Rev., 13, 686-707.

5. Clewell, D.B. (1993). Bacterial sex pheromone-induced plasmid transfer. Cell, 73, 9-12. 
6. CLSI - Clinical Laboratory Standards Institute (2005). Performance standards for antimicrobial disk susceptibility tests. $9^{\text {th }}$ ed. Wayne: National Committee for Clinical Laboratory Standards

7. Coburn, P.S.; Gilmore, M.S. (2003). The Enterococcus faecalis cytolysin: a novel toxin active against eukaryotic and prokaryotic cells. Cell Microbiol., 5, 661-669.

8. Cordeiro, J.C.R.; Silbert, S.; Reis, A.O. et al. (2004). Inter-hospital dissemination of glycopeptide-resistant Enterococcus faecalis in Brazil. Clin. Microbiol. Infect., 10, 260-262.

9. Creti, R.; Imperi, M.; Bertuccini, L. et al. (2004). Survey for virulence determinants among Enterococcus faecalis isolated from different sources. J. Med. Microbiol., 53, 13-20

10. Dalla Costa, L.M.; Souza, D.C.; Martins, L.T.F.; Zanella, R.C.; Brandileone, M.C.; Bokerman, S.; Sader, H.S.; Souza, H.A.P.H.M. (1998). Vancomycin-resistant Enterococcus faecium: first case in Brazil. Brazil. J. Infect. Dis., 2, 160-163.

11. Dalla Costa, L.M.; Reynolds, P.E.; Souza, H.A.P.H.M.; Souza, D.C.; Palepou, M.-F.; Woodford, N. (2000). Characterization of a divergent vanD-type resistance element from the first glycopeptide-resistant strain of Enterococcus faecium isolated in Brazil. Antimicrob. Agents Chemother., 44, 3444-3446.

12. Dunny, G.M.; Craig, R.A.; Carron, R.L. et al. (1979). Plasmid transfer in Streptococcus faecalis: production of multiple sex pheromones by recipients. Plasmid, 2, 454-465

13. Dutka-Malen, S.; Evers, S.; Courvalin, P. (1995). Detection of glycopeptide resistance genotypes and identification to the species level of clinically relevant enterococci by PCR. J. Clin. Microbiol., $33,24-27$.

14. Hancock, L.E.; Perego, M. (2004). The Enterococcus faecalis $f_{s r}$ Two-component system controls biofilm development through production of gelatinase. J. Bacteriol., 186, 5629-5639.

15. Kritish, C.J.; Li, Y.H.; Cvithkovitch, D.G.; Dunny, G.M. (2004). Esp-independent biofilm formation by Enterococcus faecalis. J. Bacteriol., 186, 154-163.

16. Leme, I.L.; Ferreira, A.J.P.; Bottino, J.A.; Pignatari, A.C.C. (2000). Glycopeptides susceptibility among enterococci isolated from a poultry farm in São Paulo, Brazil (1996/1997). Braz. J. Microbiol., $31,53-57$.
17. Marques, E.B.; Suzart, S. (2004). Occurrence of virulence -associated genes in clinical Enterococcus faecalis strains isolated in Londrina. J. Med. Microbiol., 53, 1069-1073.

18. Moretti, M.L.; Bratfich, O.J.; Stucchi, R.B.; Levi, C. et al. (2004). Clonal dissemination of VanA-type glycopeptide-resistant Enterococcus faecalis between hospitals of two cities located 100 km apart. Braz. J. Med. Biol. Res., 37, 1339-1343.

19. Palazzo, I.C.V.; Camargo, I.L.B.C.; Zanella, R.C. et al. (2006). Evaluation of clonality on enterococci isolated in Brazil carrying Tn1546-like elements associated to vanA plasmids. FEMS Microbiol. Lett., 258, 29-36.

20. Shankar, N.; Baghdayan, A.S.; Gilmore, M.S. (2002). Modulation of virulence within a pathogenicity island in vancomycin-resistant Enterococcus faecalis. Nature, 417, 746-750.

21. Shankar, N.; Baghdayan, A.S.; Huycke, M.M. et al. (1999). Infectionderived Enterococcus faecalis strains are enriched in esp, a gene encoding a novel surface protein. Infect. Immun., 67, 193-200.

22. Su, Y.A.; Sulavik, M.C.; He, P. et al. (1991). Nucleotide Sequence of the gelatinase gene (GelE) from Enterococcus Faecalis subsp. liquefaciens. Infect. Immun. 59, 415-420.

23. Tendolkar, P.M.; Baghdayan, A.S.; Gilmore, M.S.; Sankar, N. (2004). Enterococcal surface protein, Esp, enhances biofilm formation by Enterococcus faecalis. Infec. Immun., 72, 6032-6039.

24. Tenover, F.C.; Arbeit, R.D.; Goering, R.V. et al. (1995). Interpreting chromosomal DNA restriction patterns produced by pulsed-field gel electrophoresis: criteria for bacterial strain typing. J. Clin. Microbiol., 33, 2233-2239.

25. Waters, C.M.; Antipora, M.H.; Murray, B.E.; Dunny, G.M. (2003). Role of the Enterococcus faecalis GelE protease in determination of cellular chain length, supernatant pheromone levels, and degradation of fibrin and misfold surface proteins. J. Bacteriol., 185, 3613-3623.

26. Woodford, N. (1998). Glycopeptide-resistant enterococci: a decade of experience. J. Med. Microbiol., 47, 849-862.

27. Zanella, R.C.; Brandileone, M.C.C.; Bokerman, S.; Almeida, S.C.G.; Valderato, F.; Vitorio, F.; Moreira, M.F.A.; Villins, M.; Salomao, R.; Pignatari, A.C. (2003). Phenotypic and genotypic characterization of vanA Enterococcus isolated during the first nosocomial outbreak in Brazil. Microb. Drug Resist., 9, 283-291. 